\title{
Digestive capacity of the rabbit during the post-weaning period, according to the milk/solid feed intake pattern before weaning
}

\section{Claudio Scapinello, Thierry Gidenne*, Laurence Fortun-Lamothe}

\author{
Station de recherches cunicoles, Inra, Centre de recherche de Toulouse, \\ BP 27, 31326 Castanet-Tolosan, France
}

(Received 15 January 1999; accepted 17 May 1999)

\begin{abstract}
The milk/solid feed intake pattern and digestive capacity were compared in two groups of young rabbits reared between 16 and 32 days in litters of four (L4 group, $n=18$ litters) or ten pups (L10, $n=20$ ) in order to modulate milk availability. Compared to the LA group, rabbits in the L10 group presented a lower milk intake (22.3 versus $\left.28.8 \mathrm{~g} \cdot \mathrm{day}^{-1}\right)$ and a higher solid feed intake (12.9 versus $8.0 \mathrm{~g} \cdot \mathrm{day}^{-1}$ ) between 16 and 32 days of age. Live weight and weight gain were significantly lower in the L10 $(-15 \%)$ than in the L4 group from 22 until 42 days. No significant difference was observed among the two groups for post-weaning digestibility and for the intraluminal specific or total activities of amylase and maltase. The total intraluminal activity (pool of enzyme) of amylase and maltase doubled between weaning ( 32 days) and 42 days. At weaning, the specific activity of amylase was similar in the jejunal and ileal segments $\left(8.5 \mathrm{AU} \cdot \mathrm{g}^{-1}\right)$. From 32 to 42 days, the specific amylase activity doubled in the jejunum, while it remained steady in the ileum. The intraluminal specific maltase activity did not significantly change between 32 and 42 days, while it was twice as high in the jejunum compared to the ileum (3.5 versus $1.8 \mu$ moles hydrolysed maltose. ${ }^{-1}$, respectively). (C) Inra/ Elsevier, Paris.
\end{abstract}

digestion / weaning / rabbit / amylase / maltase

Résumé - Capacité digestive du lapereau après sevrage, en fonction de l'ingestion lait/ aliment avant le sevrage. Le profil d'ingestion (lait et aliment sec) ainsi que la capacité digestive ont été comparés sur deux groupes de lapereaux élevés, entre 16 et 32 j d'âge, en portées de dix (groupe L10, $n=20$ portées) ou en portées de quatre petits (L4, $n=20$ ), afin de moduler la disponibilité en lait. Par rapport au groupe $L 4$, les lapereaux du groupe $L 10$ présentent pendant la période $16-32 \mathrm{j}$, une plus faible ingestion de lait ( $22,3 \mathrm{vs} 28,8 \mathrm{~g} \cdot \mathrm{j}^{-1}$; figure $\mathrm{l}$ ), mais une consommation plus importante d'aliment solide (12,9 vs $\left.8,0 \mathrm{~g} \cdot \mathrm{j}^{-1}\right)$. Parallèlement, les lapereaux du groupe L10 présentent dès $22 \mathrm{j}$ d'âge un poids vif significativement inférieur ( $-15 \%$, figure 2$)$; cet écart étant maintenu jusqu'à $42 \mathrm{j}$ d'âge, ces animaux ont donc une vitesse de croissance plus faible $\left(24,6 \mathrm{vs} 28,8 \mathrm{~g} \cdot \mathrm{j}^{-1}\right)$. Aucune différence

\footnotetext{
* Correspondence and reprints

E-mail: gidenne@toulouse.inra.fr
} 
significative de digestibilité fécale des nutriments n'a été mesurée entre les groupes L10 et L4 (tableau II). De même, l'activité intraluminale totale ou spécifique de l'amylase et de la maltase (tableau III) n'a pas montré d'écart significatif entre les deux groupes. L'activité totale intraluminale (pool enzymatique, calculé pour un segment intestinal) de l'amylase et de la maltase double entre le sevrage $(32 \mathrm{j})$ et $42 \mathrm{j}$ d'âge. L'activité spécifique amylasique est similaire à $32 \mathrm{j}$ entre le jéjunum et l'iléon (8,5 AU.g ${ }^{-1}$ contenu, figure 3$)$. Durant les 2 semaines post-sevrage, l'activité spécifique amylasique double au niveau jéjunal, alors qu'elle demeure constante au niveau iléal. L'activité intraluminale spécifique de la maltase n'a pas varié significativement entre 32 et $42 \mathrm{j}$ (en moyenne $2,6 \mu$ moles maltose hydrolysé $\cdot \mathrm{g}^{-1}$ contenu frais $\left.\cdot \min ^{-1}\right)$, mais sa valeur au niveau jéjunal est double de celle mesurée au niveau iléal (resp. 3,5 et 1,8). (C) Inra/Elsevier, Paris.

digestion / sevrage / lapin / amylase / maltase

\section{INTRODUCTION}

Digestive disorders, frequently observed in rabbit breeding during the weaning period (21-40 days of age) have been related to the intake pattern (quality and quantity) and maturation of the digestive process $[17,19]$. More particularly, an incomplete intestinal digestion of starch, corresponding to an overflow of readily available carbohydrates entering the caecum, could alter microbial activity and could lead to digestive troubles $[5,16]$. An earlier intake of solid feed may improve such maturation and may result in a decreased post-weaning mortality [24]. However, the effect of a change in the intake pattern on the maturation of digestive enzymes is only slightly documented [15]. For instance, the intake behaviour of the rabbit before weaning has mainly been documented for milk but not for solid feed [20, 26]. However, the maturation of enzyme secretion implicated in glucidic digestion, according to age and starch feed intake, have been mainly obtained for the pancreas [2, $7,12,13,22]$. But almost no information is known about amylase or maltase activity in the small intestine [6]. Moreover, the global digestive capacity that could be addressed through the pool of enzymes effectively active in the lumen has never been evaluated according to the feeding behaviour of the young rabbit.

Therefore, the aim of this work was to study how the suckling rabbit adapts its feeding pattern (milk and solid feed) according to the availability of milk (modulated by litter size), and if that modulates its capacity to degrade dietary starch. In addition, we aimed at developing an original approach for the study of the glucidic digestive capacity of the rabbit around weaning, by evaluating the intestinal intraluminal (jejunum and ileum) pool of enzymes able to hydrolyse starch and maltose.

\section{MATERIALS AND METHODS}

\subsection{Animals and feeding}

To modulate the milk/feed intake pattern before weaning, 40 litters (with ten young per litter at birth, day 0 ) were submitted to a low or a high availability of milk, through a variation in litter size: on day 16, 20 litters were reduced to four pups per litter (L4 group), while the others were maintained at ten (L10 group). Litters were obtained from primiparous hybrid females (strain Inra A $1066 \times$ A 1077). Live weight and milk intake of suckling rabbits were measured individually at $16,22,25,29$ and 32 days of age.

To measure the solid feed intake of the litters without separating the young from their mothers, cages were equipped with wired separations (on day 16) allowing only the passage of the young, thus creating a space reserved for them. From day 16 until weaning (day 32) a maternal commercial feed (table I) was distributed ad libitum to the young in specific feeders (special shape, location in part reserved to the young), and to the females in feeders not accessible to the young. Solid feed intake was measured every 
Table I. Ingredients and chemical composition of feeds given to females and litters, or to growing rabbits after weaning.

\begin{tabular}{lcc}
\hline Diets & Females and litters $\$$ & Growing rabbits \\
\hline Ingredients & & \\
Barley & & 10.00 \\
Wheat & & 10.00 \\
Soybean meal & & 6.00 \\
Sunflower meal & & 12.00 \\
Lucerne meal & & 25.00 \\
Dehydrated beet pulp & & 10.00 \\
Wheat bran & & 20.35 \\
Beet molasses & & 5.00 \\
CMV* & & 1.65 \\
Chemical composition (\% DM) & 90.1 & \\
Organic matter & 19.2 & 91.6 \\
Crude protein (N*6.25) & 14.2 & 19.7 \\
Starch & 36.6 & 19.1 \\
NNCC** & 34.3 & 40.1 \\
NDF & 17.7 & 31.8 \\
ADF & 4.3 & 18.3 \\
ADL & & 4.6 \\
\hline
\end{tabular}

* Bicalcium phosphate $-0.10 \%$; calcium carbonate $-0.30 \%$; minerals, vitamins and salt $-1.00 \%$; $\mathrm{DL}_{40}$ Methionine $-0.25 \%$; Robenidine (66 ppm).

** Non-nitrogenous cellular content (OM-NDF-CP).

$\ddagger$ Commercial feed, proximate ingredients composition (cereals $11 \%$, vegetable protein source $30 \%$, fibre source $52 \%$, molasses $4 \%$, minerals and vitamins $4 \%$ ).

2 days from 16 days of age until weaning and then at 39 and 42 days of age. After weaning, rabbits were kept in individual cages, and they were fed experimental diets meeting recent nutritional recommendations, ad libitum (for description, see table I) [10].

\subsection{Digestibility measurements and collection of intestinal content}

Digestibility measurements were performed on two groups of 12 rabbits each $(L 4, L 10)$ kept in individual metabolism cages. After a 10-day adaptation period ( $32-42$ days old), the apparent digestibility coefficients were calculated from the total collection of faeces for four consecutive days (European reference method [14]). Faeces were pooled individually in plastic bags and stored at $-18{ }^{\circ} \mathrm{C}$ until subsequent analyses.

The intraluminal enzymatic activities were measured from samples of the jejunum and ileum
$(20 \mathrm{~cm})$ obtained from rabbits killed by cervical dislocation at 32 and 42 days of age, between 10.00 and 12.00 hours. After laparotomy, the digestive tract was withdrawn and the jejunal segment was identified and clamped $5 \mathrm{~cm}$ after the Treitz loop and $20 \mathrm{~cm}$ further on. Similarly, the terminal ileal segment was clamped at 25 and $5 \mathrm{~cm}$ before the ileo-caecal junction. The luminal content of the segment was then sampled by slight manual pressure, directly in a centrifugal tube maintained in ice. The overall sampling procedure did not exceed $10 \mathrm{~min}$. The tubes were then weighed and frozen at $-80^{\circ} \mathrm{C}$ until further processing.

\subsection{Analytical procedures}

Dry matter (DM) was determined on duplicate samples by heating at $103^{\circ} \mathrm{C}$ for $24 \mathrm{~h}$. Organic matter (OM) was determined by ashing at $550{ }^{\circ} \mathrm{C}$ for $5 \mathrm{~h}$. Nitrogen was determined 
according to the Dumas procedure (autoanalyseur LECO, mod. FP428). Starch was hydrolysed enzymatically and the resultant glucose was measured by using the hexokinase (EC 2.7.1.1) glucose-6-phosphate dehydrogenase (NAD) (EC 1.1.1.49) system (Boëhringer, Mannheim). Gross energy was measured with an adiabatic bomb calorimeter (PARR, Moline, IL). Acid detergent fibre (ADF), acid detergent lignin (ADL) and neutral detergent fibre (NDF) were determined according to the sequential procedure of Van Soest et al. [31]. In order to evaluate the overall content in readily available carbohydrates (starch, oligosaccharides, free saccharides, etc.), the nonnitrogenous cellular content was calculated as the difference between OM and CP and NDF.

After defrosting, samples of the intraluminal intestinal content $(1-2 \mathrm{~g})$ were diluted with $5 \mathrm{~mL}$ of a physiological solution $\left(9 \mathrm{~g} \mathrm{NaC} \cdot \mathrm{L}^{-1}\right)$ and then homogenised (Ultra-Turrax, $8000 \mathrm{tr} \cdot \mathrm{min}^{-1}$ ) and centrifuged $\left(15 \mathrm{~min},+3{ }^{\circ} \mathrm{C}, 5000 \mathrm{~g}\right)$. The supernatant was frozen at $-80{ }^{\circ} \mathrm{C}$ until subsequent analyses. Amylase activity was determined according to the procedure of Corring and Saucier [7], and was expressed as the amylolytic activity unit ' $\mathrm{AU}$ ' $\mathrm{min}^{-1} \cdot \mathrm{g}^{-1}$ fresh content (specific activity) or per gram total segment collected (total activity). AU was the quantity of enzyme which hydrolysed $1 \mathrm{mg}$ of starch at $37^{\circ} \mathrm{C}$. The maltase activity was determined according to the procedure of Dahlqvist [9], and was expressed in $\mu$ moles hydrolysed maltose $\cdot \mathrm{min}^{-1} \cdot \mathrm{g}^{-1}$ fresh content (specific activity) or per total segment collected (total activity). Following Shields et al. [29] and Kelly et al. [18], we adopted two types of expression. Specific activity was considered as a qualitative indicator of the intraluminal potential of hydrolysis of a substrate. Total activity corresponded to the pool of enzyme activity present in a segment, and could be assimilated to the intestinal hydrolysing capacity of a substrate.

\subsection{Statistical analyses}

The results were subjected to analysis of variance according to the general linear model procedure of the Statistical Analysis System [28]. Data for enzyme activity were analysed according to a three factorial model (age, site, litter size) with corresponding interactions. Interactions between site and litter, as well as between age and litter were found to be non-significant $(P>0.20)$ and are not presented in table III.

\section{RESULTS}

\subsection{Feed intake pattern, growth and faecal digestibility}

The weights of the young rabbits at birth $(50.8 \mathrm{~g})$ and on day $16(199.4 \mathrm{~g})$ as well as their milk intake on day 16 were similar in both groups. Between 16 and 32 days of age (weaning), the individual milk intake was $23 \%$ higher for the L4 than for the L10 group (460 g versus $357 \mathrm{~g} ; P<0.05$ ). This difference was more pronounced between days 20 and 26 of lactation (figure 1). A very weak feed intake was registered before day $20\left(\right.$ mean $<2 \mathrm{~g} \cdot \mathrm{d}^{-1} \cdot$ rabbit $\left.^{-1}\right)$. On day 21 , however, rabbits ate more than $2.5 \mathrm{~g} \cdot \mathrm{d}^{-1} \cdot \mathrm{rab}-$ $\mathrm{bit}^{-1}$ in ten of the 20 litters in group L10, compared to two of 18 litters in group L4. From day 16 until weaning, the solid feed intake was $62 \%$ higher in the L10 group than in the L4 group (207 versus $128 \mathrm{~g}$, $P<0.01$ ). Nevertheless, rabbits gained more weight between days 16 and 32 (figure 2) in the L4 than in the L10 group (461 g versus $394 \mathrm{~g}, P<0.05)$. Rabbits of the L4 group reached a higher $(+10 \%)$ weight at weaning (661 g versus $595 \mathrm{~g}, P<0.01$ ), and maintained a higher live weight until 42 days of age (1 $084 \mathrm{~g}$ versus $979 \mathrm{~g}, P<0.01$ ). The post-weaning (32-42 days) weight gain was, however, only slightly higher in the L4, compared to the L10 group (38.9 and $35.1 \mathrm{~g} \cdot \mathrm{d}^{-1}, P=0.08$, respectively).

The digestibility in the whole tract was not significantly different among the two groups, whatever the nutrient concerned (table II). The nutritive value of the experimental feed was in accordance with initial formulation objectives: digestible energy 'DE' = 12.65 MJ. $\mathrm{kg}^{-1} \mathrm{DM}$; digestible protein 'DP' $=154 \mathrm{~g} \cdot \mathrm{kg}^{-1} \mathrm{DM}$; and the ratio $\mathrm{DP} / \mathrm{DE}=11.7 \mathrm{~g} \mathrm{DP} / \mathrm{MJ} \mathrm{ED}$.

\subsection{Intraluminal amylolytic and maltasic activity}

The specific or total amylase and maltase activities did not differ significantly 

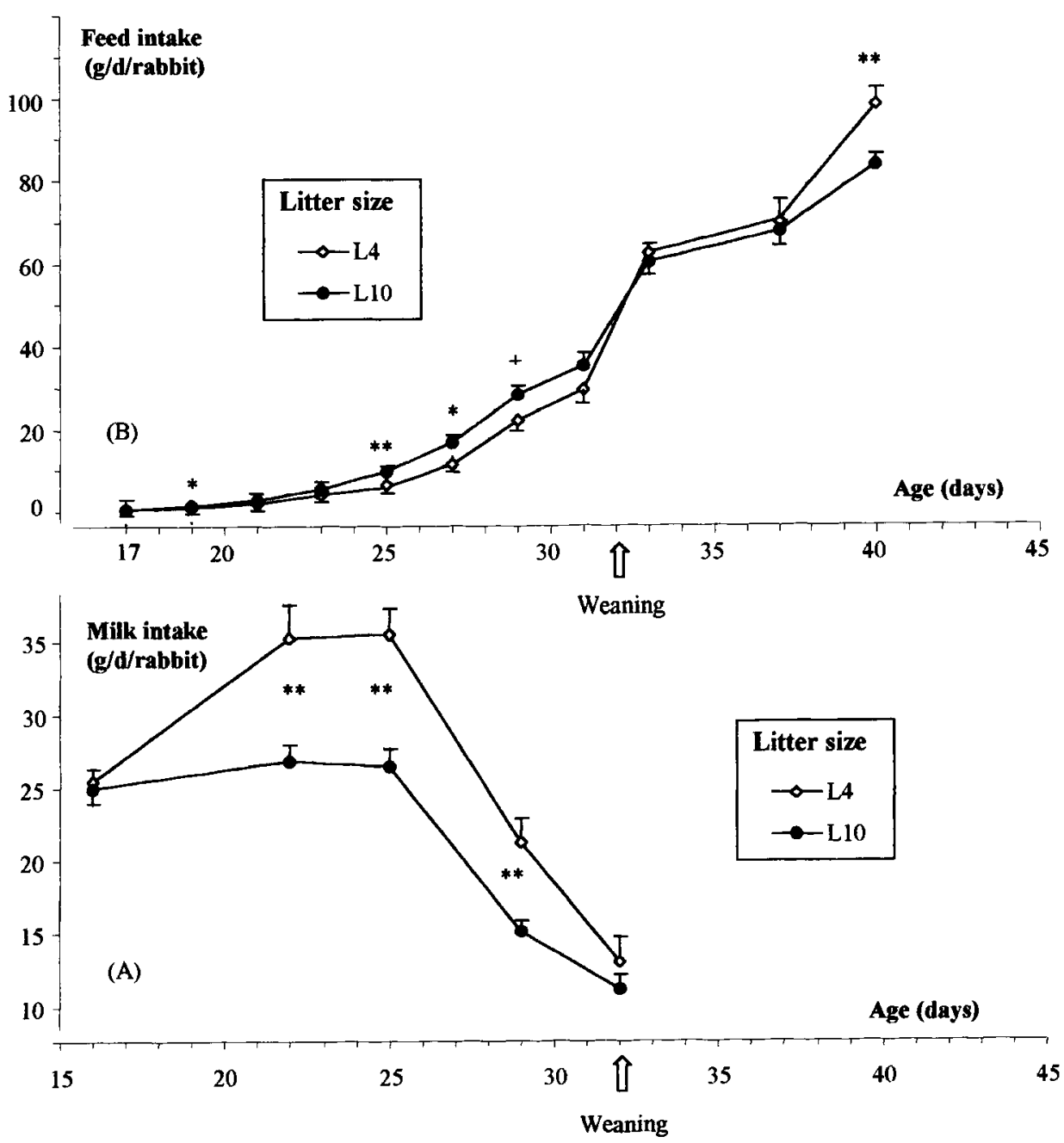

Figure 1. Milk (A) and solid feed intake (B) from 16 to 42 days of age, according to litter size (four pups: L4; ten pups: L 10) before weaning (32 days). Values are means \pm standard error of the mean (SEM). Within age, means differed significantly at the level $P<0.01\left(^{* *}\right), P<0.05\left(^{*}\right), P<0.1$ $(+)$.

among the L4 or L10 groups (table III). A significant interaction between age and site $(P<0.01)$ was observed for the specific amylase activity (table $I I I$ ). Between 32 and 42 days of age, the activity doubled in the jejunum, while it remained steady in the ileum (mean 8.5 AU.g-1 content, figure 3). A similar specific activity of maltase was observed for 32- or 42-day-old rabbits, but was twice as high in the jejunum than in the ileum segment $(P<0.01)$.

When expressed as total activity (table III), the pool of amylase and maltase almost doubled (in the jejunum and ileum, $P<0.01$ ) between 32 and 42 days of age. With respect to the intestinal segment, the total activity of 


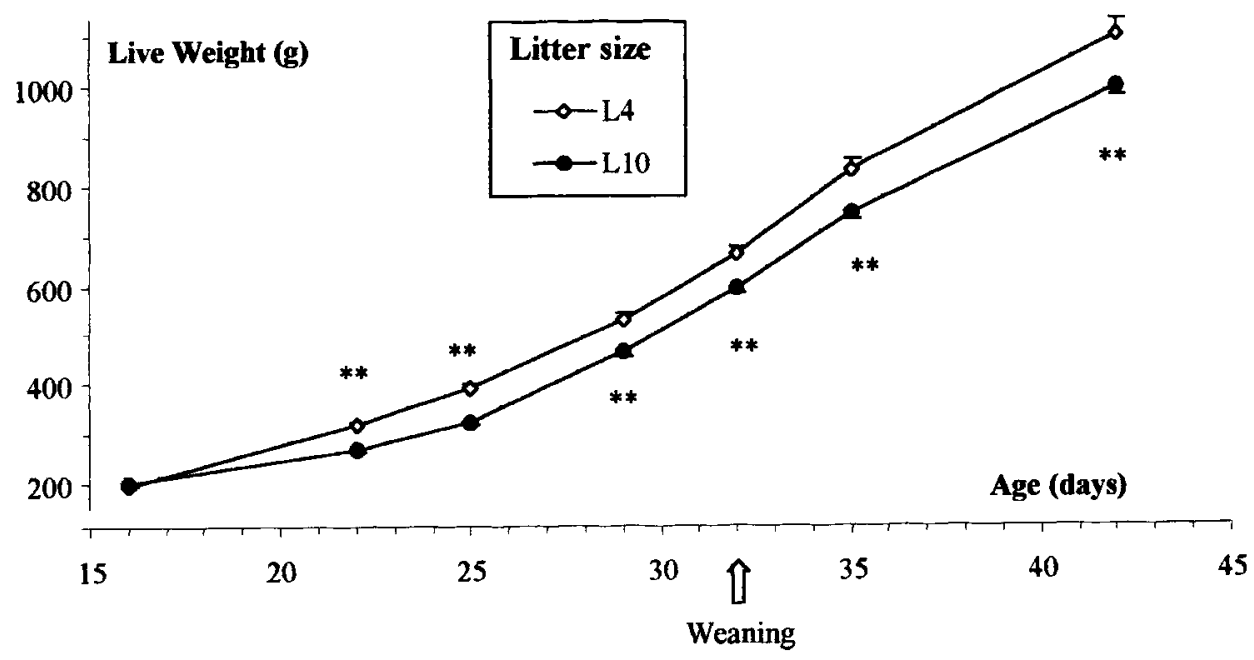

Figure 2. Growth of rabbits from 16 to 42 days of age, according to litter size (four pups: L4; ten pups: $\mathrm{L} 10$ ) before weaning (32 days). Values are means \pm standard error of the mean (SEM). Within age, means differed significantly at the level $P<0.01\left(^{* *}\right)$.

Table II. Whole tract digestibility of experimental feed (growing), measured on 42-day-old rabbits previously maintained in litters of four (L4) or ten (L10).

\begin{tabular}{lllll}
\hline Litter size & L4 & L10 & SEM & Pr $>$ F
\end{tabular}

Digestibility coefficients (\%)

\begin{tabular}{lllll} 
Organic matter & 70.8 & 70.1 & 0.46 & 0.28 \\
NNCC $^{*}$ & 95.7 & 95.6 & 0.28 & 0.93 \\
Energy & 69.4 & 68.6 & 0.47 & 0.30 \\
Crude protein & 78.7 & 77.1 & 0.66 & 0.11 \\
NDF & 34.5 & 33.4 & 0.91 & 0.41 \\
\hline
\end{tabular}

* Non-nitrogenous cellular content (OM-NDF-CP)

maltase and amylase also doubled between the jejunum and the ileum. Obviously, it was related to an increase in the intraluminal fresh content, which doubled for the ileum $(3.46 \mathrm{~g}$ versus $7.11 \mathrm{~g}, P<0.01$ ) while it increased by only $32 \%$ for the jejunum ( $1.23 \mathrm{~g}$ versus $1.81 \mathrm{~g}, P<0.10)$.

\section{DISCUSSION}

Until the age of 16 days, the rabbit exclusively consumed milk, and began to eat some pellets of solid feed between 18 and 20 days of age (a mean of $2 \mathrm{~g} \cdot \mathrm{day}^{-1} \cdot \mathrm{rabbit}^{-1}$ ). A previous report [24] mentioned no significant pellet intake before the age of 22-23 days. Unfortunately, because the young must be reared in litters, we could not measure the individual solid feed intake, and we were therefore not able to estimate the interindividual variability. In agreement with the results of De Blas et al. [11], the total mean solid feed intake before weaning was $170 \mathrm{~g} \cdot \mathrm{rabbit}^{-1}$. But it increased by $38 \%$ in the litters of ten while their milk intake was $22 \%$ lower than in the litters of four. These results suggested that under competition for milk intake, the beginning of solid feed intake occurred earlier and the feed/milk intake ratio was higher. Furthermore, considering that the mean DM level of milk between days 16 and 32 of lactation is $32 \%[21,27]$, the total DM intake (milk + pellets) for rabbits reared in litters of ten 


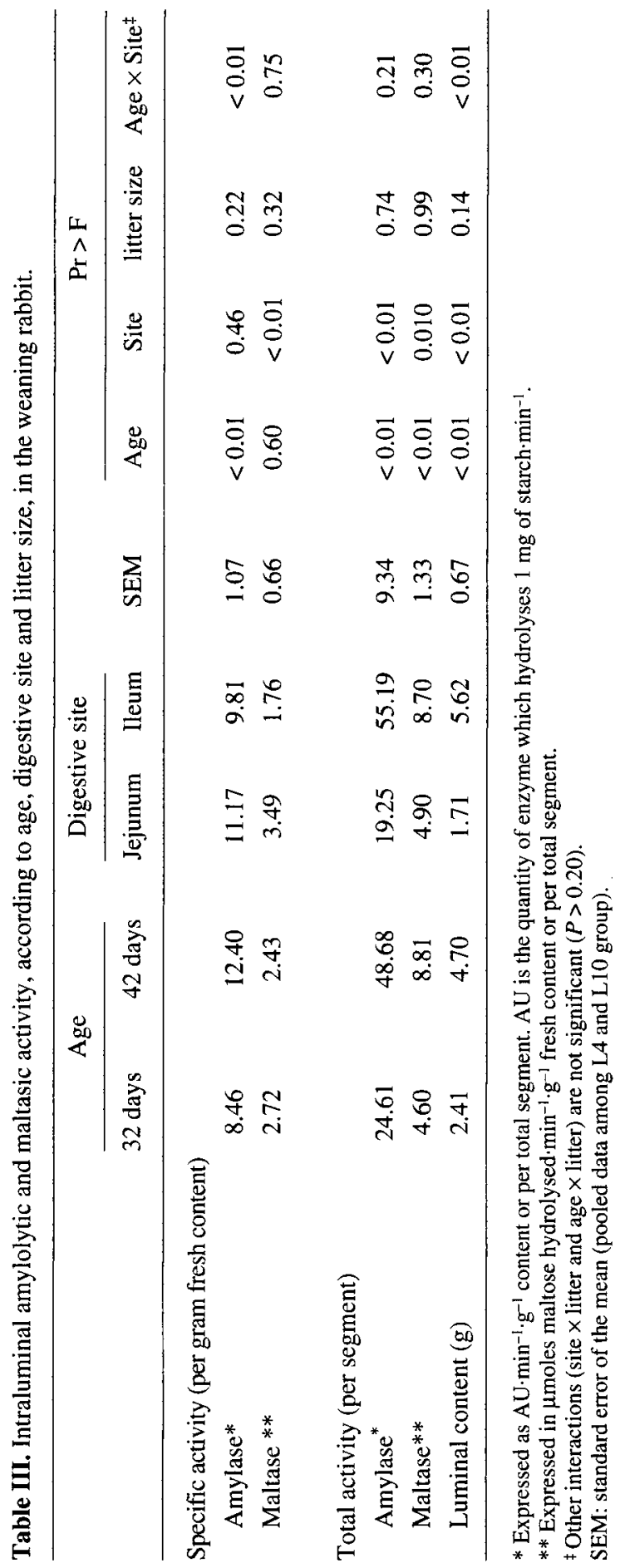




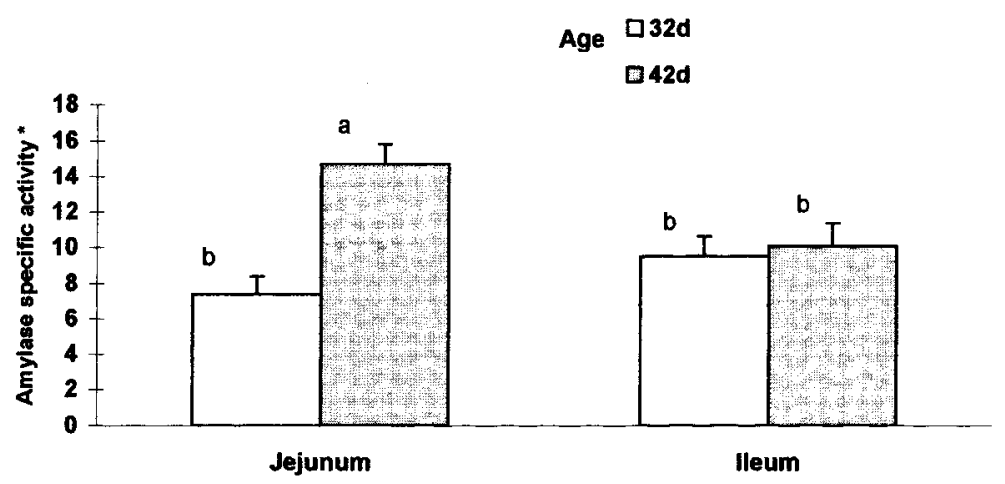

Figure 3. Intraluminal amylolytic specific activity, according to age and digestive site. * Mean values ( \pm SEM), expressed as the amylasic unit 'AU' $\mathrm{min}^{-1} \cdot \mathrm{g}^{-1}$ fresh content. $\mathrm{a}, \mathrm{b}$ : means having a common superscript letter did not significantly differ at $P<0.05$.

was $14 \%$ higher than those raised in litters of four ( 300 and $262 \mathrm{~g} \mathrm{DM}$ for the 16-32-day period, respectively). This compensatory effect of pellet intake was not, however, sufficient to ensure a post-weaning growth similar to that of rabbits kept in a litter of four. These results were in agreement with McNitt and Moody [26], who reported a higher weaning weight and growth during the post-weaning period, when the pups consumed more milk during lactation.

This modulation in the milk/solid feed intake ratio did not seem to affect the overall post-weaning feed digestion. More particularly, the degradation of the glucidic fraction (NNCC, mainly starch and simple saccharides) in the whole tract (intestinal + microbial digestion) was almost complete as previously reported $[4,11,17]$. Similarly, the feeding behaviour before weaning did not affect the post-weaning intestinal capacity to degrade starch or maltose, either estimated through the intraluminal (jejunum or ileum) specific or total activity of amylase or maltase. This was consistent with Corring et al. [7] who reported that the pancreatic amylase level was not affected by a shorter sucking period (until 21 days instead of 30 days, without dry feed).

The digestive capacity for starch hydrolysis, estimated by measuring the amylase and maltase total intraluminal activities, doubled during the ten post-weaning days. Between weaning and 3 months of age, Marounek [25] also reported a three-fold increase in total intestinal amylolytic activity. Because the luminal content doubled as well, this suggested a four-fold increase in enzyme secretion from the pancreas and intestine. This sharp increase in the starch digestive capacity after weaning was also suggested by the measurements in the starch level in the ileal contents that decreased sharply during the two post-weaning weeks [4]. Besides the effect of age, we cannot exclude an effect of dietary starch by itself on amylase activity as classically observed in other species. However, it was only recently described in adult rabbits [1], and not for the growing rabbit [8]. During the ten post-weaning days, an increase in the enzymatic intraluminal specific activity was measured in the jejunum only for amylase, in agreement with Marounek [25]. The origin of this increase of the amylolytic activity remains unclear. Amylase is mainly secreted by the pancreas; however, in adult rabbits the secretion of amylase by the duodenal mucosa was also observed [6], but was ten times lower than pancreatic secretion [1]. Corring et al. [25] demonstrated the importance of ontogenic factors compared to dietary factors on amylolytic pan- 
creatic activity around the weaning period. However, the results should be considered with caution, since the increase in pancreatic amylase varied greatly according to the authors between 15 and 43 days of age: 60 or 5 times or no variations $([2,8,13]$, respectively). Inversely, the specific intraluminal maltase activity did not change during the ten post-weaning days. This was consistent with the results of Toofanian [30], who reported an increase in maltasic activity of the intestinal mucosa only between 20 and 30 days of age, and no change after weaning. A similar trend was also observed in piglets $[3,23]$. Therefore, the development of maltase activity would be mainly controlled by ontogenic factors rather than by nutritional factors. We observed, however, a lower maltasic activity in the lumen of the ileum compared to the jejunum. This was in agreement with the results of Dojana et al. [13], obtained for the ileal and jejunal mucosa. This was also confirmed for the relationship between measurements of maltase in the lumen and in the mucosa of the small intestine.

In conclusion, a change in the milk/solid feed intake pattern before weaning did not lead to major changes in the post-weaning digestive capacity. We confirmed that starch digestion sharply increases during the two post-weaning weeks, although the specific maltase activity evolved independently of age. Further investigations are now necessary to specify the impact of nutrient intake before weaning (particularly the available carbohydrate/fibre ratio) on the digestive system development and nutrient digestibility.

\section{ACKNOWLEDGEMENTS}

The authors thank André Lapanouse, Jacques De Dapper and Muriel Ségura for their technical assistance (Station de recherches cunicoles, Inra Toulouse). This study was supported by a postdoctoral fellowship grant of $\mathrm{CNPq}$ (National Council for Scientific and Technological Development - Brazil), and by U.C.A.A.B. (ChâteauThierry, France).

\section{REFERENCES}

[1] Abbas T.A.K., Abdel-Latif A., Osman A.M., Responses of rabbit digestive enzymes amylase and lipase to food composition and intermittent heat exposure, World Rev. Anim. Prod. 26 (1991) 81-86.

[2] Alus G., Edwards N.A., Development of the digestive tract of the rabbit from birth to weaning, Proc. Nutr. Soc. 36 (1977) 3 A.

[3] Aumaitre A., Corring T., Development of digestive enzymes in the piglet from birth at 8 weeks. 2-Intestine and intestinal disaccharidases, Nutr. Metab. 22 (1978) 244-255.

[4] Blas E., Gidenne T., Digestion of starch and sugars, in: De Blas C., Wiseman J. (Eds.), The Nutrition of the Rabbit, CAB Int., Wallingford, 1998, pp. 17-38.

[5] Blas E., Fandos J.C., Cervera C., Gidenne T., Perez J.M., Effet de la nature et du taux d'amidon sur l'utilisation digestive de la ration chez le lapin au cours de la croissance, $5^{\mathrm{c}} \mathrm{J}$. Rech. Cunicoles (1990) comm. 50.1-50.9.

[6] Catala J., Bonnafous R., Variations de l'activité alpha-amylasique pariétale et intraluminale dans le tube digestif de lapins témoins et à canal pancréatique ligaturé, Ann. Biol. Anim. Biochim. Biophys. 19 (1979) 813-817.

17] Corring T., Saucier R., Sécrétion pancréatique sur porc fistulé. Adaptation à la teneur en protéines du régime, Ann. Biol. Anim. Biochim. Biophys. 12 (1972) 233-241.

[8] Corring T., Lebas F., Courtot D., Contrôle de l'évolution de l'équipement enzymatique du pancréas exocrine du lapin, de la naissance à 6 semaines, Ann. Biol. Anim. Biochim. Biophys. 12 (1972) 221-231.

[9] Dahlqvist A., Rat intestinal dextranase. Localization and relation to the other carbohydrases of the digestive tract, Biochim. J. 86 (1963) 72-81.

[10] De Blas J.C., Mateos G.G., Feed formulation, in: De Blas C., Wiseman J. (Eds.), The Nutrition of the rabbit, CAB Int., Wallingford, 1998, pp. 241-254.

[11] De Blas J.C., Taboada E., Mateos G.G., Nicodemus N., Mendez J., Effect of substitution of starch for fiber and fat isoenergetic diets on nutrient digestibility and reproductive performance of rabbits, J. Anim. Sci. 73 (1995) 1131-1137.

[12] Dojana N., Constantin N., Research on serum and pancreatic amylase and lipase activity in rabbits fed with starch and vegetable oil enriched food, Scientific papers USA Bucuresti 37 (1994) 22-29.

[13] Dojana N., Costache M., Dinischiotu A., The activity of some digestive enzymes in domestic rabbits before and after weaning, Anim. Sci. 66 (1998) 501-507.

[14] E.G.R.A.N., European reference method for in vivo determination of diet digestibility in rabbits, World Rabbit Sci. 3 (1995) 41-43. 
[15] Fekete S,, Recent findings and future perspectives of digestive physiology in rabbits: a review, Acta Veterinaria Hungarica 37 (1989) 265-279.

[16] Gidenne T., Caeco-colic digestion in the growing rabbit: impact of nutritional factors and related disturbances, Livest. Prod. Sci. 51 (1997) 73-88.

[17] Gidenne T., Perez J.M., Effect of dietary starch origin on digestion in the rabbit, 1. Digestibility measurements from weaning to slaughter, Anim. Feed Sci. Technol. 42 (1993) 237-247.

[18] Kelly D., Smyth J.A., Mc Cracken K.J., Digestive development of the early weaned pig, 1. Effect of continuous nutrient supply on the development of the digestive tract and on changes in digestive enzyme activity during the first week post-weaning, Br. J. Nutr. 65 (1991) 169-180.

[19] Laplace J.P., Le transit digestif chez les monogastriques, III- Comportement (prise de nourriture, caecotrophie), motricité et transit digestif et pathogénie des diarrhées chez le lapin, Ann. Zootech. 27 (1978) 225-265.

[20] Lebas F., Alimentation et croissance du lapereau sous la mère, Rec. Med. Vet. 146 (1970) 1065-1070.

[21] Lebas F., Composition chimique du lait de lapine, évolution au cours de la traite et en fonction du stade de lactation, Ann. Zootech. 20 (1971), 185-192.

[22] Lebas F., Corring T., Courtot D., Equipement enzymatique du pancréas exocrine chez le lapin, mise en place et évolution de la naissance au sevrage. Relation avec la composition du régime alimentaire, Ann. Biol. Anim. Biochim. Biophys. 11 (1977) 399-413.
[23] Leibholz Z., Wheat starch in the diet of pigs between 7 and 28 days of age, Anim. Prod. 35 (1982) 199-207.

[24] Maertens L., De Groote G., Feed intake of rabbit kit before weaning and attempts to increase it, J. Appl. Rabbit Res. 13 (1990) 151-158.

[25] Marounek M., Vovk S.J., Skrivanova V., Distribution of activity of hydrolytic enzymes in the digestive tract of rabbits, Br. J. Nutr. 73 (1995) 463-469.

[26] McNitt J.I., Moody J., Milk intake and growth rates of suckling rabbits, J. Appl. Rabbit Res. 11 (1988) 117-119.

[27] Parigi Bini R., Xiccato G., Cinetto M., Dalle Zotte A., Digestive efficiency and energy and protein retention in suckling and weanling rabbits, Zootec. Nutr. Anim. 17 (1991) 167-180.

[28] Statistical Analysis System, in: SAS/STAT Guide for personal computers, Statistic relase 6.02, SAS Institute Inc., Cary, NC, 1987.

[29] Shields R.G., Ekstrom K.E., Mahan D.C., Effect of weaning age and feeding method on digestive enzyme development in swine from birth to 10 weeks, J. Anim. Sci. 50 (1980) 257-265.

[30] Toofanian F., The fetal and postnatal development of small intestinal disaccharidases in the rabbit, Lab. Anim. Sci. 34 (1984) 268-271.

[31] Van Soest P.J., Robertson J.B., Lewis B.A., Methods for dietary fiber, neutral detergent fiber, and non starch polysaccharides in relation to animal nutrition, J. Dairy Sci. 74 (1991) 3583-3597. 